\title{
Prirodna i antropogena osnova turizma Hrvatske
}

\section{Pavlo Ružić}

Institut za poljoprivredu i turizam Poreč, Hrvatska

e-mail:pavlo@iptpo.hr

\section{Damir Demonja}

Institut za razvoj i međunarodne odnose, Zagreb, Hrvatska e-mail:ddemonja@irmo.hr

\begin{abstract}
SAŽETAK U radu se istražuje ruralni turizam Hrvatske s aspekta njegovih prirodnih i društvenih razvojnih posebnosti. Temeljni ciljevi istraživanja su detektiranje posebnosti razvoja ruralnoga turizma Hrvatske. U vezi s ciljevima postavljena je hipoteza kojom se tvrdi da Hrvatska raspolaže prirodnim i društvenim atraktivnostima s kojima može razviti poseban, zanimljiv, prihvatljiv, konkurentan i održiv ruralni turistički proizvod. Istraživanje u ovome radu temeljeno je na sekundarnim izvorima, te analizi pristupa i stavova o ruralnom turizmu domaćih i stranih autora. U radu su istražene i protumačene pretpostavke je li moguće razvijati ruralni turizam u Hrvatskoj i kakav je intenzitet njegova razvoja moguć.
\end{abstract}

Ključne riječi: Hrvatska, ruralni turizam, ruralni prostor, ruralni turistički proizvod.

\section{Uvod}

Razvoj ruralnoga turizma Hrvatske započeo je sporadično početkom 90-ih godina prošloga stoljeća, a sustavno od 1995. godine kada je Ministarstvo turizma Republike Hrvatske pokrenulo inicijative i prve aktivnosti vezane za obilazak terena, prikupljanje informacija i edukaciju inicijatora. Nedugo nakon toga ustrojen je "Savjet za ruralni turizam" koji je kasnije prerastao u "Savjet za razvoj maloga i srednjega poduzetništva u turizmu", s naglaskom na ruralni turizam (Kušen, 1995.). U to vrijeme razvoj cjelokupnoga ruralnog turizma svodio se na razvoj turističkih seljačkih gospodarstava. Aktivnosti Hrvatskoga farmera, tadašnjega Saveza seljaka, Ministarstva turizma Republike Hrvatske, Instituta za turizam iz Zagreba i, kasnije, Kluba članova 
"Selo" i Hrvatske gospodarske komore, bile su, u početku, usmjerene na traženje pogodnih poljoprivrednih gospodarstava (imanja) i animiranje njihovih vlasnika da ih urede za pružanje turističko-ugostiteljskih usluga, te na stvaranje uvjeta za njihov razvoj.

Sustavni razvoj ruralnoga turizma u Hrvatskoj može se podijeliti u dva važna razdoblja. Prvi je započeo 1995. i trajao je do kraja 1999. godine, kada je objavljen nacionalni program "Razvoj maloga i srednjega poduzetništva u turizmu, s naglaskom na održivi razvoj turizma u ruralnom prostoru". Nakon toga, slijedilo je nekoliko godina stanke, tek s pojedinačnim inicijativama, i nedostajalo je potpore resornoga ministarstva. Drugo razdoblje, koje bilježi pomake u razvoju ove vrste turizma, započinje krajem 2003., odnosno početkom 2004. godine, kada su u Hrvatskoj izrazitije pokrenuti resori poljoprivrede i turizma, te se počinje voditi značajnija briga o ruralnom prostoru i gospodarskim djelatnostima na ruralnim područjima.

Aktivnostima resora poljoprivrede i turizma u Hrvatskoj je potaknut interes za ruralnim turizmom. Danas se na ruralnom području Hrvatske bilježi ukupno 21188 kreveta: 933 kreveta na obiteljskim poljoprivrednim turističkim gospodarstvima (OPTG), 4060 kreveta u lječilištima, 1600 mjesta u kampovima i 6593 u hotelima, pansionima, prenoćištima, turističkim naseljima i drugdje. U navedenim objektima u 2008. godini ostvareno je 838000 dolazaka (posjetitelja) i 1662000 noćenja (Demonja i Ružić, 2010.:68-69). Navedenim podacima obuhvaćeni su posjetitelji i noćenja u planinskim mjestima i u 12 županija ruralne Hrvatske, po svim vrstama smještaja koji su zastupljeni na ruralnom prostoru Hrvatske, dakle u hotelima, pansionima, turističkim naseljima, kampovima i obiteljskim poljoprivrednim turističkim gospodarstvima (OPTG). Također, posjeti i noćenja ostvareni su konzumiranjem svih oblika ponude: u lječilištima, na skijalištima, posjetima prirodnim i kulturnim dobrima, u lovu, ribolovu, i drugima.

Uspoređujući ostvarena noćenja ruralne (kontinentalne) Hrvatske s ukupno ostvarenim noćenjima, uočava se da noćenja u ruralnoj Hrvatskoj sudjeluju sa svega 2,9\%, što je malo u odnosu na udjel noćenja ruralnoga turizma od 10\% do 20\%, koji se ostvaruje u europskim okvirima (Demonja i Ružić, 2010.:70).

Važno je naglasiti da potražnju, odnosno posjete ruralnoj turističkoj destinaciji u Hrvatskoj motivira, između ostalih činitelja, intenzivni užitak, aktivnosti u prirodi, naglašena potreba za doživljajima, rekreacija i briga za zdravlje. Posebna motivacija potražnje je inovativnost i inscenacija, koja osim osnovnih standarda omogućuje neobična iskustva, iznenađenja i poticaje. Turisti dobivaju ugođajnu ili emocionalnu dodatnu korist (ambijent, doživljaj, zabavu, avanturu, kontakt s drugim gostima, i slično). Kao odgovor na brzi ritam života suvremenoga turista, raste potražnja za ekološki čistim područjima Hrvatske. Naposljetku, treba istaknuti osobnu sigurnost, koja postaje jedan od glavnih kriterija odluke za odmorom u ruralnim područjima, te sve veća briga za vlastito zdravlje. 


\section{Teorijske osnove proučavanja posebnosti razvoja ruralnoga turizma}

\subsection{Privlačnost ruralnih prostora: mogućnosti ugodnoga odmora i rekreacije}

Još od antičke Grčke poznato je da je ruralno područje privlačilo ljude za provođenje odmora i ugodnoga života. Svemu tomu svjedoče različiti primjeri putovanja na ruralna područja, kao što su putovanja na olimpijske igre, posjeti proročanstvima i ljekovitim izvorima. I u rimsko doba poznata su putovanja i odmaranja na ruralnom prostoru: u termalnim kupalištima i vilama (ljetnikovcima) građenima u prirodnim područjima (Weber i Mikačić, 1995.:39-40). Oblici/vrste putovanja slični današnjim turističkim putovanjima javljaju se i u srednjem vijeku. Tipični primjeri putovanja u to doba su hodočašća i lovni pohodi.

Ruralna područja i danas su vrlo zanimljiva turistima. Više je razloga tome, a jedan od njih je što ruralna područja pružaju različite mogućnosti zabave i razonode. Prema popisu Vijeća Europe, turističke aktivnosti na ruralnom području su brojne. Na spomenutom popisu razlikuje se više od 30 turističkih aktivnosti svrstanih u 7 skupina, kao što su: ture, aktivnosti na vodi (rijekama i jezerima), aktivnosti u zraku, sportske aktivnosti, aktivnosti otkrivanja zanimljivosti, aktivnosti radnih procesa, kulturne aktivnosti, aktivnosti zdravstvenoga karaktera, i brojne druge (Ružić, 2009.:14). Prema navedenim turističkim aktivnostima na ruralnom prostoru u Hrvatskoj moguće je razvijati 19 oblika turizma, čiju recentnu detaljnu razradu i tumačenje su napravili Demonja i Ružić (2010.:29-36). Kao sastavnice ruralnoga turizma načelno mogu biti uključeni agroturizam, aktivnosti u prirodi, eko-turizam, ruralno iskustvo, kulturni turizam, avanturistički turizam, izletnički (countryside) turizam, i slični oblici turizma (Meler, 2010). Prirodne i društvene karakteristike ruralnih područja privlačne su turistima i mogu stvoriti snažnu ponudu (Hajek, 2002.; Meler, 2010.).

Karakteristike ruralnoga prostora Hrvatske kao snažni privlačni činitelji ruralnoga turizma istaknute su u "Strategic Marketing Plan of Croatian Tourism for period 2010-2014 [SMPCT]” (SMPCT, 2009.:426) i uključuju: prirodno naslijeđe, netaknutu prirodu, hrvatski karakter i tradiciju (način života, gostoljubivost, običaje, itd.), slikovita sela, i slično. Iz navedenih razloga tržišni cilj ruralnoga turizma trebao bi biti pozicioniranje Hrvatske kao odredišta kontinentalnoga/ruralnoga turizma.

\subsection{Prirodne i društvene atraktivnosti: temelji razvoja ruralnoga turizma}

Prirodne i društvene atraktivnosti kao temelji razvoja ruralnoga turizma predmet su istraživanja u radovima brojnih autora. Među njima Jurcan (1989.) razvoj turizma na ruralnom prostoru temelji na prirodnim i društvenim atraktivnostima. Kušen (1997.) daje strateški okvir razvoja ruralnoga turizma kao dio koncepta cjelokupnoga razvoja ruralnoga prostora i obnove sela. Također, Kušen (2002.) je razradio sustav turističkih atrakcija, kao osnovu za evaluaciju temeljnih turističkih resursa za razvoj ruralnoga turizma Hrvatske. Poseban doprinos proučavanju turizma i održivoga ra- 
zvoja Hrvatske svojim istraživanjima i radovima dale su Cetinski i Katica (1998.). Aktualno stanje razvoja ruralnoga turizma u Hrvatskoj, temeljeći ga na prirodnim i društvenim atrakcijama, opsežno su obradili i protumačili Demonja i Ružić (2010.:44-84).

Nastanak i određenje turističke atrakcijske osnove ruralnoga prostora, kao potencijala razvoja ruralnoga turizma, protumačio je Kušen (2007.), koji objašnjava da je ruralni prostor izvorno služio kao životni prostor poljoprivrednika, i da je ruralni prostor, zapravo, cjelokupni obradiv i naseljiv prostor izvan gradova. Nadalje, Kušen ističe da su na ruralnom prostoru nastali: tradicijsko selo, ruralne cjeline, tradicijska ruralna arhitektura i tradicijski interijeri, tradicijski vrtovi, te ekološki, proizvodno i oblikovano uravnoteženi kulturni pejzaž. Na tom materijalnom temelju paralelno se razvijala tradicijska kultura života i rada seljaka (tradicijska znanja i tehnologije poljoprivredne proizvodnje i načina stanovanja, odijevanja, prehrane i zajedništva), koja je u konačnici rezultirala i nematerijalnim dobrima, kao što su plesovi, pjesme, legende, i slično. Sve to predstavlja pretežni, prepoznatljiv i najvrjedniji dio turističke atrakcijske osnove ruralnoga prostora, koja čini razvojni resurs ruralnoga turizma. I drugi autori, primjerice Pena, Jamilena, Molina (2012.), tvrde da su ruralne turističke destinacije određene svojstvima činitelja ponude, prirodnom i kulturnom ponudom, te ponudom domaćih proizvoda i gastronomije.

\subsection{Ruralni prostori: motivatori dolaska turista posebno onih iz urbanih sredina}

Ruralni prostor je zanimljiv za odmor i rekreaciju, posebno za urbanu populaciju. Rezultati istraživanja (Kastenholz, Lima, 2011.) pokazuju da je ruralni prostor suprotnost urbanom, i idealan je za boravak obitelji s djecom, te ugodan za odmor i rekreaciju. Osim navedenoga, ruralni prostor omogućava upoznavanje starina i tradicije. Također, rezultati istraživanja pokazuju da ruralna turistička destinacija intenzivno privlači i udovoljava potrebama turista, i da se, pritom, štite od propadanja njezini prirodni, kulturni i socijalni resursi.

Promjene obilježja ruralnih prostora, njegovih ekonomskih aktivnosti i funkcija utječu na percepciju ruralnoga. Ruralni prostor je područje izvan gradskoga (urbanoga) prostora koji obilježava mali broj stanovnika $s$ dominantnim korištenjem zemlje i šuma za opstanak, na kojem se prepoznaje društvena struktura, običaji i seoski identitet (Ružić, 2009.). Danas postoje različita stajališta o tome što su ruralni prostori, što bi mogli biti, što bi trebali biti i kako to postići (Butler i Hall, 1998.). Koncepti mjesta i identiteta ključni su za marketing turističke destinacije, ali su i iznimno važni za konzumaciju turističkih iskustava jer konzumentu nude osjećaj autentičnosti, jedinstvenosti i, time, socijalne dinstinkcije (Mowl, 2001.).

Ruralni prostori svojim karakteristikama motiviraju posjet turista. Motivi koji turizam na ruralnom prostoru čine zanimljivim i prihvatljivim (Duk-Byeong, Yoo-Shik, 2008.) klasificiraju se prema tipologiji (Goeldner i Ritchie, 2003.) kako slijedi: 1. fizički motivi, kao što je relaksacija, 2. kulturni motivi, kao što su otkrivanje novih 
prostora, 3. interpersonalni motivi, kao što su socijalizacija i upoznavanje novih ljudi i 4. motiv prestiža, kao što su samoupoznavanje i samoaktualizacija.

Ruralni prostor pogodan je za one turiste koji traže autentičnost, nostalgičnost za lijepom prošlosti. On savršeno integrira čovjeka s prirodom, pruža aktivnosti na otvorenim prirodnim ambijentima, omogućuje opuštanje u mirnoj i spokojnoj okolini daleko od gradskih gužvi i obaveza (Frochot, 2005.; Lane, 2009.) U radovima i istraživanjima brojnih autora susrećemo se s različitim polazištima sagledavanja motivacije u ruralnom turizmu, primjerice prema nacionalnosti (Cha et al., 1995.), destinaciji (Jang and Cai, 2002.), zadovoljstvu i lokaciji (Yoon and Uysal, 2005.), seniorima (Jang and Wu, 2006.) i događanjima (Lee et al., 2004.).

\section{Metodologija i pristup istraživanju}

Istraživanje u ovome radu temelji se na sekundarnim izvorima, te analizi pristupa i stavova o ruralnom turizmu domaćih i stranih autora. Budući da je osnovna namjera ovoga rada detektiranje razvojnih posebnosti ruralnoga turizma Hrvatske, istraživanje polazi od pretpostavki da se razvoj temelji na atraktivnom ruralnom prostoru, te atraktivnim objektima sa zanimljivom i prihvatljivom ponudom. Nadalje, razvoj ruralnoga turizma Hrvatske temelji se na liberalnoj turističkoj politici i zakonskoj regulativi koja podupire razvoj, a ima uporište u svestranom interesu i sklonostima stanovništva i zajednice. Naposljetku, ruralni turizam Hrvatske temelji se na relativno sačuvanom seoskom identitetu, pretpostavkama održivosti i atraktivnim činiteljima.

U ovome radu, prije svega, detektirat će se razvojne posebnosti ruralnoga turizma Hrvatske, a u svezi toga postavljena je hipoteza kojom se tvrdi da Hrvatska raspolaže prirodnim i društvenim atraktivnostima s kojima može razviti poseban, zanimljiv, prihvatljiv, konkurentan i održiv ruralni turistički proizvod. Dokazivanje postavljene hipoteze provodi se teorijski bez terenskih istraživanja na ruralnom prostoru Hrvatske. Očekuje se da bi takva istraživanja trebala uslijediti tek nakon što se prihvati teorijska osnova ustanovljena u ovom radu, a ovaj rad mogao bi poslužiti kao inicijalna podloga za realizaciju te zadaće.

\section{Rezultati istraživanja}

Rezultati istraživanja u ovome radu odnose se na detektiranje i određenje posebnosti razvoja ruralnoga turizma Hrvatske. U tom smislu posebno se istražuje ruralni prostor s gledišta pretpostavki i činitelja razvoja. Pritom se detektiraju pretpostavke koje omogućuju razvoj, te činitelji koji diktiraju intenzitet i smjer razvoja ruralnoga turizma u Hrvatskoj. Dobri izgledi za razvoj ruralnoga turizma u Hrvatskoj temelje se na atraktivnosti njezinoga ruralnog prostora, interesu i sklonosti stanovništva, i društva u cjelini, prema razvoju, kao i liberalnoj turističkoj politici i zakonskoj regulativi koje omogućuju razvoj. 


\subsection{Prirodni činitelji razvoja ruralnog turizma Hrvatske}

Ruralni prostor u Hrvatskoj određuje se prema podjeli po kojoj se manje administrativne jedinice, općine, smatraju ruralnim područjima, a gradovi urbanim. Primjenom OECD kriterija, prema kojemu se područja klasificiraju kao ruralna ili urbana temeljem praga od 150 stanovnika na km², 91,6\% ukupnoga područja Hrvatske klasificira se kao ruralno, a 8,4\% kao urbano. Prema tom kriteriju 88,7\% naselja smješteno je u ruralnim područjima, a 11,3\% u urbanim, s 35\% stanovništva u 14 gradova s više od 30000 stanovnika, dok 47,6\% ukupnoga stanovništva živi u ruralnim područjima, a njih 52,4\% u urbanim (MPRRR RH, 2008.:7).

S obzirom na različitosti prirodno-resursne osnove i obilježja ruralne arhitekture i običaja, u Hrvatskoj je moguće razlikovati sedam ruralnih cjelina: 1. Slavonija, Baranja i Srijem; 2. Hrvatsko zagorje, Prigorje, Međimurje i Podravina; 3. Posavina, Pokuplje, Moslavina; 4. Gorski kotar i Žumberak; 5. Lika i Kordun; 6. Istra i Hrvatsko primorje i 7 . Dalmacija.

Hrvatska je, kako ističe Kušen (2007.), zemlja brojnih turističkih atraktivnosti od kojih su za razvoj ruralnoga turizma bitne sljedeće: kopnene vode, prije svega rijeka Dunav, ali i druge rijeke, osobito Korana, Krka i Cetina; masiv Velebita; plodna Panonska nizina - Slavonija, Posavina, Podravina, Baranja i Srijem; brdsko-planinska područja - Gorski kotar, Lika, Kordun, Banovina, Hrvatsko zagorje, Međimurje i Moslavina; vinorodna područja; povijesni gradovi na kontinentu; dvorci Hrvatskoga zagorja; hrvatska svetišta, toplice i, na kraju, velik, slikovit, raznolik i turistički privlačan ruralni prostor. Atraktivnosti ruralnoga područja Hrvatske, od posebne važnosti za razvoj ruralnoga turizma, su: klima, kopnene vode, reljef, životinjske i biljne vrste (biološka raznolikost), zaštićena područja, šume i obradive površine (poljoprivreda). (O njima će više riječi biti u nastavku).

Jedno od važnijih obilježja ruralnoga prostora Hrvatske je klima. Hrvatska se nalazi u umjerenom klimatskom pojasu sjeverne polutke. Zbog takvoga položaja njezine klimatske prilike su povoljne i umjerene bez temperaturnih krajnosti. Pravilna je izmjena sva četiri godišnja doba. Prosječno trajanje insolacije u Hrvatskoj smanjuje se od zapada $\mathrm{k}$ istoku i od sjevera prema jugu. Najmanju insolaciju imaju najviši vrhovi planina i sjeveroistok Hrvatske, a najveću dalmatinski otoci (Hvar 2674 sata) i južna Hrvatska. Umjerenost klime rezultat je ne prehladnih zima i ne previše vrućih ljeta. Najhladniji mjesec je siječanj, s prosječnim temperaturama od $-2^{\circ} \mathrm{C}$ u gorskoj Hrvatskoj do $5^{\circ} \mathrm{C}$ u primorskoj. Najtopliji mjesec je srpanj, s prosječnim temperaturama od $15^{\circ} \mathrm{C}$ u gorskoj Hrvatskoj do $24^{\circ} \mathrm{C}$ u primorskoj.

Nadalje, kopnene vode u Hrvatskoj predstavljaju značajni razvojni potencijal ruralnoga turističkog odredišta (tablica 1.).

Kada je riječ o vodama u Hrvatskoj, prema izvješću UNESCO-a o opskrbljenosti vodom u 188 zemalja svijeta, Hrvatska zauzima treće mjesto u Europi, iza Norveške i Islanda. Kako se navodi u izvješću, Hrvatska raspolaže s 32818 metara kubičnih obnovljive pitke vode po stanovniku godišnje, što je svrstava među trideset zemalja najbogatijih vodom na svijetu (Meler, 2010.:195). 
Tablica 1.

Kopnene vode u Hrvatskoj

\begin{tabular}{|c|c|}
\hline Vrste kopnenih voda & Naziv i opći podaci \\
\hline Rijeke & $\begin{array}{l}\text { Dunav (ukupno } 2857 \mathrm{~km} \text {, u Hrvatskoj } 188 \mathrm{~km} \text { ) } \\
\text { Sava (ukupno } 945 \mathrm{~km} \text {, u Hrvatskoj } 562 \mathrm{~km} \text { ) } \\
\text { Drava (ukupno } 707 \mathrm{~km} \text {, u Hrvatskoj } 505 \mathrm{~km} \text { ) } \\
\text { Mura (ukupno } 438 \mathrm{~km} \text {, u Hrvatskoj } 53 \mathrm{~km} \text { ) } \\
\text { Kupa (ukupno } 296 \mathrm{~km} \text {, u Hrvatskoj } 296 \mathrm{~km} \text { ) } \\
\text { Neretva (ukupno } 225 \mathrm{~km} \text {, u Hrvatskoj } 20 \mathrm{~km} \text { ) } \\
\text { Una (ukupno } 212 \mathrm{~km} \text {, u Hrvatskoj } 120 \mathrm{~km} \text { ) } \\
\text { Bosut (ukupno } 186 \mathrm{~km} \text {, u Hrvatskoj } 151 \mathrm{~km} \text { ) } \\
\text { Korana (ukupno } 134 \mathrm{~km} \text {, u Hrvatskoj } 134 \mathrm{~km} \text { ) } \\
\text { Bednja (ukupno } 133 \mathrm{~km} \text {, u Hrvatskoj } 133 \mathrm{~km} \text { ) } \\
\text { Ušće Vuke u Dunav u Vukovaru } \\
\text { Neretva (jadranski sliv) } \\
\text { Cetina (jadranski sliv) } \\
\text { Zrmanja (jadranski sliv u Dalmaciji) } \\
\text { Krka (jadranski sliv u Dalmaciji) } \\
\text { Čikola (jadranski sliv u Dalmaciji) } \\
\text { Dragonja (u Istri) } \\
\text { Mirna (u Istri) } \\
\text { Raša (u Istri) } \\
\text { Boljunčica (u Istri) } \\
\text { Pazinčica (ponornica u Istri) } \\
\text { Gacka (ponornica u Lici) } \\
\text { Krbava (ponornica u Lici) }\end{array}$ \\
\hline Jezera & $\begin{array}{l}\left.\text { Peručko (oko } 13 \mathrm{~km}^{2}\right) \\
\text { Butoniga u Istri } \\
\text { Lokvarsko (Gorski kotar) } \\
\text { Fužinsko (Gorski kotar) } \\
\text { Krušćičko u Lici } \\
\text { Dubravsko na Dravi } \\
\text { Vransko kod Biograda }\left(30,7 \mathrm{~km}^{2}\right) \\
\text { Vransko na Cresu }\left(6 \mathrm{~km}^{2}\right) \\
\text { Prokljansko } \\
\text { Visovačko } \\
\text { Veliko i Malo jezero na Mljetu } \\
\text { Baćinska jezera kod Ploča } \\
\text { Crveno i Modro jezero kod Imotskog } \\
\text { Plitvička jezera (nacionalni park, uvrštena u svjetsku prirodnu baštinu } \\
\text { UNESCO-a) }\end{array}$ \\
\hline Ribnjaci & $\begin{array}{l}\text { Jasinje ili Jelas kod Broda }\left(20 \mathrm{~km}^{2}\right) \\
\text { Siščani kod Čazme }\left(18 \mathrm{~km}^{2}\right) \\
\text { Končanica kod Grubišnoga polja }\left(\text { oko } 14 \mathrm{~km}^{2}\right)\end{array}$ \\
\hline Termalni izvori & $\begin{array}{l}\text { Bizovac (1974.) } \\
\text { Brestovac (1909.) } \\
\text { Daruvar (Rimsko doba) (1772.) } \\
\text { Istarske toplice (Rimsko doba ) (1817.) } \\
\text { Ivanić Grad (1989.) } \\
\text { Krapinske toplice (Rimsko doba) (1779.) } \\
\text { Lipik (Rimsko doba) (1839.) } \\
\text { Sisačko jodno lječilište (1932.) } \\
\text { Stubičke toplice (Rimsko doba) (1776.) } \\
\text { Topusko (Rimsko doba) (1818.) } \\
\text { Varaždinske toplice (Rimsko doba) (1820.) }\end{array}$ \\
\hline
\end{tabular}

Izvor: Demonja, D. i Ružić, P. (2010). Ruralni turizam u Hrvatskoj s hrvatskim primjerima dobre prakse $i$ europskim iskustvima, str. 146-147. 
Za turizam posebno su zanimljivi prostori koji imaju određene oblike reljefa iz horizontalne i vertikalne razvedenosti. Hrvatska se dijeli na tri osnovne prirodne cjeline koje se međusobno nadopunjuju, odnosno čine komplementarnost prostora: 1. nizinska ili panonska prirodna regija (obuhvaća 55\% teritorija i na njoj živi $66 \%$ stanovništva); 2. primorska ili jadranska prirodna regija (obuhvaća $31 \%$ teritorija i ondje živi 31\% stanovništva) i 3. gorska ili dinarska prirodna regija (obuhvaća 14\% teritorija i tamo obitava 3\% stanovništva).

Prostori iznad 1500 metara čine 0,11\% ukupnoga hrvatskog teritorija, a riječ je o sljedećim planinama (Demonja, Ružić 2010.:148): 1. Dinara (Dinara 1831 m), 2. Kamešnica (Kamešnica 1810 m), 3. Biokovo (Sv. Jure 1762 m), 4. Velebit (Vaganski vrh 1758 m), 5. Plješivica (Ozeblin 1657 m), 6. Velika Kapela (Bjelolasica 1533 m), 7. Risnjak (Risnjak 1528 m), 8. Svilaja (Svilaja 1508 m), i 9. Snježnik (Snježnik $1506 \mathrm{~m})$.

I životinjske vrste, koje se zadržavaju u nekim područjima, povećavaju njegovu turističku atraktivnost. Bogatstvo vrsta divljači u šumama i riba u vodama, ne samo što uljepšavaju i čine kraj/područje zanimljivim, nego pružaju mogućnosti za lov i ribolov, istraživanje, fotografiranje, brigu za njihovo preživljavanje/održavanje i druge aktivnosti (tablica 2.).

Tablica 2.

Rezervati i spomenici prirode, zaštićene biljne i životinjske vrste u Hrvatskoj

\begin{tabular}{|c|c|}
\hline $\begin{array}{l}\text { Vrsta rezervata i/ili spomenika } \\
\text { prirode }\end{array}$ & Naziv/opis rezervata $\mathrm{i} / \mathrm{ili}$ spomenika prirode \\
\hline 1. Strogi rezervati & $\begin{array}{l}\text { Hajdučki i Rožanski kukovi na Velebitu } \\
\text { Bijele i Samarske stijene na Velikoj Kapeli }\end{array}$ \\
\hline 2. Nacionalni parkovi & $\begin{array}{l}\text { Plitvička jezera } \\
\text { Paklenica } \\
\text { Risnjak } \\
\text { Mljet } \\
\text { Kornati } \\
\text { Brijuni } \\
\text { Krka } \\
\text { Sjeverni Velebit }\end{array}$ \\
\hline 3. Parkovi prirode & $\begin{array}{l}\text { Kopački rit kraj Osijeka } \\
\text { Zapadni dio Medvednice } \\
\text { Planina Velebit } \\
\text { Planina Biokovo } \\
\text { Telašćica } \\
\text { Lonjsko polje }\end{array}$ \\
\hline 4. Specijalni rezervati & $\begin{array}{l}\text { a) } 34 \text { rezervata šumske vegetacije } \\
\text { b) } 10 \text { botaničkih vrtova } \\
\text { c) } 2 \text { zoološka vrta } \\
17 \text { ornitoloških rezervata } \\
2 \text { ihtiološka rezervata (izvorišni dio i obalni pojas } \\
\text { rijeke Vrlike kod Imotskog) } \\
\text { d) } 2 \text { rezervata u moru (more i podmorje Limskog } \\
\text { kanala i područje Malostonskog zaljeva) }\end{array}$ \\
\hline 5. Park šume & 20 lokacija park šuma \\
\hline
\end{tabular}




\begin{tabular}{|c|c|}
\hline $\begin{array}{l}\text { Vrsta rezervata } \mathrm{i} / \mathrm{ili} \text { spomenika } \\
\text { prirode }\end{array}$ & Naziv/opis rezervata $\mathrm{i} / \mathrm{ili}$ spomenika prirode \\
\hline 6. Značajni krajolici & 51 lokacija značajnih krajolika \\
\hline 7. Spomenici prirode & $\begin{array}{l}\text { a) } 10 \text { geografskih i geoloških spomenika prirode } \\
\text { b) } 1 \text { geološko-paleontološki spomenik prirode } \\
\text { (Velnačka glavica u Brušanima kod Gospića) } \\
\text { c) } 4 \text { paleontološka spomenika prirode (polupećina } \\
\text { Hušnjakovo kraj Krapine, Grapčeva pećina na Hvaru, } \\
\text { pećina Vindija kraj Donje Voće, Hrvatsko zagorje, } \\
\text { Mačkova (velika) pećina u Velikoj Sutinskoj (Hrvatsko } \\
\text { zagorje) } \\
\text { d) } 27 \text { geomorfoloških spomenika prirode } \\
\text { e) } 20 \text { prirodnih spomenika rijetkih primjeraka drveća i } \\
\text { njihovih skupina }\end{array}$ \\
\hline 8. Hortikulturni spomenici & $\begin{array}{l}\text { a) } 74 \text { parka } \\
\text { b) } 2 \text { aboretuma (Opeka kraj Varaždina, Trsteno kraj } \\
\text { Dubrovnika) } \\
\text { c) } 3 \text { botanička vrta (u Modrić-docu pod Zavižanom, } \\
\text { botanički vrt Farmaceutsko-biokemijskog fakulteta } \\
\text { Sveučilišta u Zagrebu, te botanički vrt Prirodoslovno- } \\
\text { matematičkoga fakulteta Sveučilišta u Zagrebu) } \\
\text { d) } 51 \text { pojedinačno stablo i njihove skupine }\end{array}$ \\
\hline 9. Spomen-područja i spomen-objekti & $\begin{array}{l}\text { a) } 28 \text { spomen-područja } \\
\text { b) } 8 \text { spomen-objekata }\end{array}$ \\
\hline 10. Pojedine biljne $\mathrm{i}$ životinjske vrste & $\begin{array}{l}\text { a) } 44 \text { biljne vrste } \\
\text { b) } 34 \text { životinjske vrste }\end{array}$ \\
\hline
\end{tabular}

Izvor: Demonja, D., Ružić, P. (2010). Ruralni turizam u Hrvatskoj s hrvatskim primjerima dobre prakse $i$ europskim iskustvima, str. 149-151.

Ukupni broj poznatih vrsta u Hrvatskoj je oko 37 000, od čega su 1136 endemi. Riječ je o velikom broju u odnosu na površinu Hrvatske, pa se, s obzirom na biološku raznolikost, Hrvatska može svrstati među najbogatije zemlje Europe. Prema raznolikosti biljnih vrsta, Hrvatska (s $0,075 \mathrm{vrsta} / \mathrm{km}^{2}$ ili $0,094 \mathrm{vrsta} / \mathrm{km}^{2}$ uključujući podvrste) zauzima treće mjesto u Europi. Fauna Hrvatske izrazito je bogata vrstama iz skupine šišmiša (34 vrste) i ptica (375 vrsta), a prisutne su i sve tri vrste velikih zvijeri (medvjed, vuk i ris).

Zaštićena područja Hrvatske obuhvaćaju 8,54\% njezine ukupne površine, odnosno $11,38 \%$ hrvatskoga kopnenog dijela. Od toga 4,76\% su nacionalni parkovi i parkovi prirode. Do sada je na području Hrvatske u Upisnik zaštićenih prirodnih vrijednosti upisano 461 zaštićeno područje, a 9 ih je pod preventivnom zaštitom. Zaštićena mjesta, nacionalni parkovi, u Hrvatskoj su: 1. Brijuni, 2. Kornati, 3. Krka, 4. Mljet, 5. Paklenica, 6. Plitvička jezera, 7. Risnjak i 8. Sjeverni Velebit. Nacionalni parkovi Plitvička jezera i Mljet uključeni su u UNESCO-vu svjetsku baštinu (UNESCO. World Heritage Centre. Croatia, 2012.).

Hrvatska je jedna od rijetkih zemalja s bogatim i raznovrsnim šumskim fondom koji prekriva 37\% njezinoga ukupnog teritorija. Najveći postotak šuma na jedinici površine ima gorska Hrvatska. Prema osnovnim vegetacijskim vrstama najveći dio hrvatskih šuma su one bjelogorične ili listače (oko 80\% svih šuma), manji dio četinjače 
(oko 13\% svih šuma) dok najmanji dio čine mješovite šume (oko 7\% svih šuma). U primorskoj Hrvatskoj karakteristični je degradirani šumski pokrov, pa je najveći dio površina pod makijom, šikarama i kamenjarom.

Poljoprivreda u ruralnom području važan je činitelj razvoja turizma. Razvoj poljoprivrede na nekom prostoru ovisi od brojnih pretpostavki, a posebno se izdvajaju: postojanje poljoprivrednoga zemljišta, povoljni klimatski, pedološki i drugi uvjeti za razvoj poljoprivrede i povoljno tržišno-ekonomsko okruženje.

Od ukupno $29557 \mathrm{~km}^{2}$, potencijalno obradive površine u Hrvatskoj obuhvaćaju 21 $491 \mathrm{~km}^{2}$, a trajno neobradiva tla, zbog nepovoljnih fizikalnih ili kemijskih svojstava, zauzimaju $8066 \mathrm{~km}^{2}$. Od navedenih potencijalno obradivih površina sada se obrađuje svega $10920 \mathrm{~km}^{2}$, a $1100 \mathrm{~km}^{2}$ koristi se kao pašnjaci. Poljoprivredne površine zauzimaju 52,2\% kopnenoga prostora Republike Hrvatske. Od toga je oko 80\% poljoprivrednih površina u privatnom vlasništvu, a približno $20 \%$ su državna zemljišta. Za razvoj ruralnoga turizma posebnu važnost ima ekološka poljoprivreda, koja je integrativna s turizmom i ostalim gospodarstvom. Od razvoja ekološke poljoprivrede i njezinoga uključivanja u (ruralni) turizam mogu se ostvariti brojni ekonomsko-financijski, sociološki, demografski i drugi učinci.

Temeljni uvjeti za razvoj ekološke poljoprivrede su, prije svega, zemljište koje ne smije biti zagađeno kemijskim i drugim sredstvima dotadašnjom uporabom, te očuvana i zdrava okolina. Na prostoru Hrvatske ispunjeni su temeljni uvjeti za razvoj ekološke poljoprivrede, a njezino područje obilježavaju izuzetne agroekološke različitosti, odnosno mogućnosti različite poljoprivredne proizvodnje i prerade u koje se mogu uključiti ribarstvo, marikultura, poljoprivreda i prerada poljoprivrednih proizvoda.

U tablici 3. nabrojani su samo neki od mogućih proizvoda ili prerađevina poljoprivrede, koji bi se odmah mogli zaštititi kao ekološki, kao i oni koji bi se u vrlo kratkom roku mogli zaštititi kontrolom proizvodnje.

Tablica 3.

Moguća ekološka poljoprivredna proizvodnja i prerada u Hrvatskoj

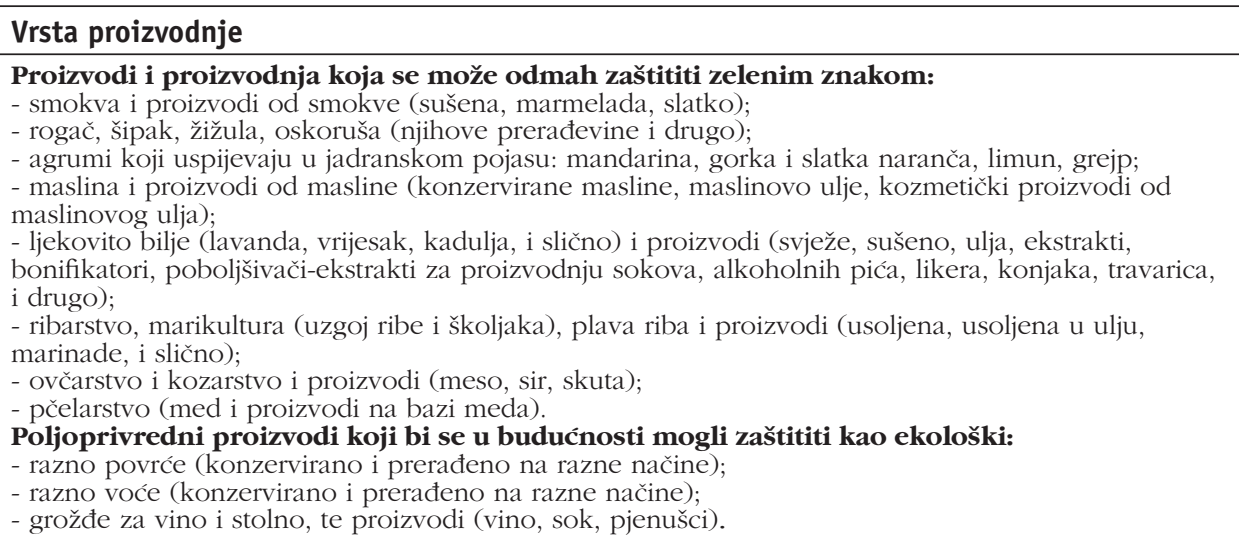


Na temelju iznesenoga moguće je zaključiti da Hrvatska raspolaže efektnim prirodnim kapitalom s kojim može ostvariti konkurentsku prednost na turističkom tržištu. Sinergijske efekte prirodnoga kapitala Hrvatske potrebno je iskoristiti, kao i komplementarnost rastućega fenomena eko-turizma sa snažnim uzletom ekološki uzgojene hrane i, općenito, tržišta zelenih proizvoda. Hrvatska s prednostima prirodnoga kapitala može stvoriti jak i uvjerljiv globalni zeleni brand.

\subsection{Društveni činitelji razvoja ruralnoga turizma Hrvatske}

Prostor je privlačan posjeduje li društvene atrakcije u koje se ubrajaju: spomenici kulture, pučka kultura, stanovanje i prehrana, narodni pučki običaji i pučka materijalna kultura sa starim zanatima, proizvodima, suvenirima, kulturne ustanove i priredbe, te zabavne, sportske i gospodarske manifestacije (tablica 4. i tablica 5.). Među glavnim prednostima razvoja ruralnoga turizma u Hrvatskoj, osim bogatstva prirodnoga okoliša (planine, rijeke, otoci, šume, itd.), su (SMPCT, 2009.:86): selo, koje je zadržalo tradicionalni, autentični hrvatski karakter (stil života, gostoljubivost, običaje, lokalna događanja, itd.), tipični mediteranski stil života (pitoreskna sela, maslinovo ulje, vinske ceste, itd.), raznolika kulturna ponuda ruralnih područja (povijest, glazba, itd.), izvrsna lokalna gastronomija i dobar stav lokalnih sudionika prema razvoju turizma.

Tablica 4.

Važnija spomenička baština ruralne Hrvatske

\begin{tabular}{|l|l|}
\hline Vrsta spomeničke baštine & Naziv/Kratki opis \\
\hline Srednjovjekovni gradići & $\begin{array}{l}\text { Dvigrad, ostaci utvrđenoga srednjovjekovnog grada u zapadnom } \\
\text { dijelu središnje Istre kod Kanfanara. } \\
\text { Grožnjan, naselje u središnjem dijelu Istre kod Buja. } \\
\text { Hum, središnja Istra, poznat po gradskim vratima iz 1562. godine, } \\
\text { zvoniku iz 1552. godine, župnoj crkvi sagradenoj 1802. godine na } \\
\text { mjestu starije iz 1609. godine, slikama iza glavnoga oltara, kaležu i } \\
\text { ciboriju iz 1539. godine. } \\
\text { Motovun, naselje u središnjem dijelu Istre, s očuvanim zidinama iz } \\
\text { 13.-14. stoljeća, renesansnom palačom-kaštelom s pregradnjama iz } \\
\text { 16.-17. stoljeća. } \\
\text { Pazin, središnja Istra, navodi se u ispravi cara Otona II. izdanoj u } \\
\text { Veroni 07. 06. 983. godine. Poznat je po Kaštelu sagrađenom na } \\
\text { litici ponad ponora Jama, prvi puta spominje se 983. godine. Župna } \\
\text { crkva spominje se 1226. godine. U Kaštelu je smješten Etnografski } \\
\text { muzej Istre, osnovan 1955. godine. } \\
\text { Vodnjan, gradić u Istri, sa sačuvanim osebujnim srednjovjekovnim } \\
\text { izgledom. Prvi puta spominje se 1150. godine. U mjesnoj crkvi sv. } \\
\text { Blaža čuva se zbirka od stotinjak ukrašenih drvenih relikvijara (15.- } \\
\text { 19. st.). Većina predmeta iz zbirke donesena je iz Venecije 1818. } \\
\text { godine. }\end{array}$ \\
\hline
\end{tabular}




\begin{tabular}{|l|l|}
\hline Vrsta spomeničke baštine & Naziv/Kratki opis \\
\hline \multirow{4}{*}{ Utvrde i dvorci } & Bilje \\
& Bosiljevo \\
& Dubovac \\
& Bežanec \\
& Ilok \\
& Klenovnik \\
& Mali Tabor \\
& Novigrad na Dobri \\
& Ozalj \\
& Ribnik \\
& Trakošćan \\
& Veliki Tabor \\
\hline
\end{tabular}

Izvor: Kamping udruženje Hrvatske. Kulturna baština Hrvatske. Pregledano 25. ožujka 2012. (http://www.camping.hr/hr/hrvatska/kulturno-nasljedstvo).

Hrvatska je bogata raznovrsnom kulturnom baštinom. Osim brojnih materijalnih ostataka, koji svjedoče o kontinuiranoj prisutnosti čovjeka na ovim prostorima, očuvan je i veliki dio nematerijalne baštine. Hrvatska je zemlja živih (pra)ostataka pradavnih običaja i vjerovanja, njihovih transformiranih i ponovno oživljenih oblika. Razni običaji i znanja predstavljaju se na brojnim manifestacijama i priredbama u zemlji i svijetu, a sve više se implementiraju i u suvremeni život.

Tablica 5.

Popis značajnije hrvatske kulturne baštine

\begin{tabular}{|c|c|}
\hline Vrsta baštine & Opis baštine \\
\hline Govor & $\begin{array}{l}\text { Govor otoka Suska } \\
\text { Žminjski govor } \\
\text { Bednjanski govor } \\
\text { Istro-rumunjski govori } \\
\text { govor posavskoga sela Siče } \\
\text { govor Huma na Sutli } \\
\text { govor i toponimija sela Vidonje } \\
\text { kajkavski donjosutlanski (ikavski) dijalekt }\end{array}$ \\
\hline Glazba & $\begin{array}{l}\text { Plesovi: linđo, balun } \\
\text { Pjevanje: bećarac, klapsko pjevanje, pjevanje "dvoglasnih tijesnih intervala" } \\
\text { ili "na tanko i debelo" u Istri } \\
\text { Tradicionalna glazbala: tambura, gajde, fićoške, drombulje, diplice, svirale }\end{array}$ \\
\hline Ophodi & $\begin{array}{l}\text { Kraljice, betlemaši, u Cvitnicu Jelo (Bošnjaci), Jela (Račinovci), kiti bunar } \\
\text { (Babina Greda), Adam i Eva (Županja), jahači }\end{array}$ \\
\hline Svatovski običaji & Bednjanska svadba na bednjanskom govoru \\
\hline Manifestacije & $\begin{array}{l}\text { Đakovački vezovi, Vinkovačke jeseni, Varaždinske barokne večeri, } \\
\text { Đurđevac - } \\
\text { Legenda o Picokima }\end{array}$ \\
\hline Rukotvorstvo & $\begin{array}{l}\text { Tkanje na stanu, pravila održavanja i odijevanja tradicionalne narodne } \\
\text { nošnje, zlatovez i svilovez, splet i rasplet, valjanje vune, tradicionalne frizure } \\
\text { i oglavlja }\end{array}$ \\
\hline Hrana & $\begin{array}{l}\text { Brački vitalac, lički sir škripavac, sinjski arambašići, slavonski kulen/kulin, } \\
\text { soparnik, zagorski mlinci, štrukli, istarski pršut }\end{array}$ \\
\hline
\end{tabular}




\begin{tabular}{|l|l|}
\hline Vrsta baštine & Opis baštine \\
\hline Igre & Sinjska alka, moreška, igra loptom u Trilju, picigin \\
\hline $\begin{array}{l}\text { Liturgijski i pučki } \\
\text { običaji }\end{array}$ & Sela diljem ruralne Hrvatske \\
\hline Obrti i umijeća & $\begin{array}{l}\text { Licitarska srca, batana, građevinske vještine (izrada krova, nabijanje } \\
\text { zemljanoga poda, izrada zida od naboja, pletenje ograde od šiblja, mazanje } \\
\text { pletera), lončarstvo, medičarstvo i licitarstvo, ugljenarenje, bunarenje, } \\
\text { tradicijske tehnike ukrašavanja uskrsnih jaja, licitarska srca, šaranje tikvica, } \\
\text { šibenska kapa, umijeće izgradnje rovinjske batane }\end{array}$ \\
\hline
\end{tabular}

Izvor: Demonja, D., Ružić, P. (2010). Ruralni turizam u Hrvatskoj s hrvatskim primjerima dobre prakse $i$ europskim iskustvima, str. 161.

Razonodi i zabavi turista pridonose raznovrsne i brojne priredbe koje se organiziraju u turističkim mjestima (tablica 6.).

Tablica 6.

Važnija kulturna, sportska i gospodarska događanja u ruralnoj Hrvatskoj

\begin{tabular}{|c|c|}
\hline Vrsta događanja & Naziv događanja \\
\hline Hrvatski filmski festivali & $\begin{array}{l}\text { Motovunski filmski festival } \\
\text { Vukovarski filmski festival }\end{array}$ \\
\hline Manifestacije nacionalnih manjina & $\begin{array}{l}\text { Dani kulture Roma } \\
\text { Dani češke kulture u Bjelovaru } \\
\text { Mikluševačko ljeto } \\
\text { Narodne nošnje na razglednicama } \\
\text { Petrovačko zvono }\end{array}$ \\
\hline Hrvatske književne manifestacije & $\begin{array}{l}\text { Croatia rediviva: ča, kaj, što baštinski dani } \\
\text { Dani kršćanske kulture } \\
\text { Dobrojutro more } \\
\text { Festival fantastične književnosti Pazin } \\
\text { Goranovo proljeće } \\
\text { Istrakon } \\
\text { Kijevski književni susreti } \\
\text { Kvirinovi poetski susreti } \\
\text { Liburnicon } \\
\text { Pjesnički susreti u Drenovcima } \\
\text { Susret čakavskih pjesnikinja otoka Hvara } \\
\text { Čakavski sabor }\end{array}$ \\
\hline Sportske manifestacije & Olimpijada pučkih igara \\
\hline Gospodarske manifestacije & $\begin{array}{l}\text { Bjelovarski sajam } \\
\text { Agrozemlja } \\
\text { Prvi sajam agroturizma Šibensko-kninske županije } \\
\text { Kulturno-gospodarska manifestacija vinogradara i vinara } \\
\text { Slavonije i Baranje BONAVITA } \\
\text { VINISTRA Poreč }\end{array}$ \\
\hline
\end{tabular}

Izvor: Demonja, D., Ružić, P. (2010). Ruralni turizam u Hrvatskoj s brvatskim primjerima dobre prakse $i$ europskim iskustvima, str. 165. 
Seoski identitet, posebno tradicijski, važan je u razvoju ruralnoga turizma. U ruralnim destinacijama diljem Hrvatske seoski identitet vidljiv je u sljedećim oblicima:

- uređenju kamenih i drvenih kuća, i u selima koja se obnavljaju pod nadzorom konzervatorskih zavoda i zavoda za zaštitu spomenika kulture. U obnovi se koriste prirodni materijali, kamen, drvo, a izbjegava pretjerano betoniranje, asfaltiranje, plastika, i drugi umjetni materijali;

- tradicijskim alatima skupljenim i prezentiranim turistima u privatnim zbirkama i muzejskim postavima;

- organiziranim turističkim prijemima, zabavama, priredbama, smotrama s izvođačima u tradicijskoj odjeći i obući, s tradicijskim glazbalima i plesom;

- organizaciji turnira pučkih igara, olimpijada s pučkim igrama u trajanju više dana;

- obnovi i zaštiti tradicijskih komunalnih objekata (izvora pitke vode, lokava, puča, putova, staza) i stavljajući ih u funkciju vodenoga parka, biciklističke staze i slično;

- $\quad$ uređenju okućnica na tradicijski način (cvjećnjak, dvorište, vrt);

- urecenju prirodnih atrakcija u okolici i njihovom osposobljavanju za posjete turista;

- ukrašavanju prostorija u agroturističkim i ostalim objektima u ruralnoj sredini sa slikama i motivima seoskoga identiteta;

- $\quad$ uređenju etno-kuća, gospodarskih zgrada, obnovi tradicijskih zanata i radionica, etno-sela sa svim elementima seoskoga identiteta (štale sa životinjama, gnojnice, stogovi sjena i slame, vrtovi s voćem i povrćem, cvjetnjaci, i drugo) i

- $\quad$ uređenju etno-muzeja s postavama života i rada na selu u prošlosti.

Turisti u selima diljem Hrvatske mogu vidjeti i doživjeti domaće životinje, uređene kuće i sela s očuvanim elementima tradicijske gradnje, uređene bare, poljske putove kojima je namijenjena turistička svrha, probati jela pripremljena na tradicijski način i druge elemente seoskoga identiteta. Očuvani seoski identitet, namijenjen u turističke svrhe, također je važna pretpostavka razvoja turizma na ruralnom prostoru Hrvatske.

\subsection{Interes stanovništva i zajednice za razvoj ruralnoga turizma}

U Hrvatskoj je evidentan interes većega dijela stanovništva i zajednice za razvoj ruralnoga turizma. Stanovništvo je uključeno u razvoj s brojnim registriranim turističkim seljačkim obiteljskim gospodarstvima pružateljima usluga turistima i kreatorima vlastitih poduzetničkih ideja i primjerima dobre prakse. Prema posljednim službenim podacima Hrvatske gospodarske komore, Sektora za turizam, iz 2007. godine, u Hrvatskoj je registrirano 379 turističkih seljačkih obiteljskih gospodarstava, s ukupno 933 kreveta, njih 314 pruža usluge prehrane, a 231 su kušaonice vina/rakije (Mišćin i Mađer, 2008.).

U poduzetničkim projektima u ruralnom turizmu u Hrvatskoj identificirane su sljedeće vrste objekata, odnosno oblici ruralnoga turizma, a za svaki su izdvojeni, predstavljeni i/ili obrađeni primjeri dobre prakse (Demonja i Ružić, 2010.:203-238): 1. Turistička seljačka obiteljska gospodarstva (TSOG); 2. Vinotočja na vinskim cestama; 
3. Kušaonice; 4. Izletišta, odnosno objekti tradicijskoga pripremanja i usluživanja toplih i hladnih jela, te pića i napitaka; 5. Smještaj na ruralnom prostoru: vinotočja s ponudom smještaja, tradicijske i druge ruralne kuće za odmor, Bed \& Breakfast, ruralni hotel, sobe, apartmani, kampovi i ruralna kamp odmorišta; 6. Stara sela (tzv. eko-etno sela) i gospodarstva sa zbirkama etnografskih predmeta; 7. Eko-gospodarstva i organsko-biološka (ekološka) poljoprivreda; 8. Male etnografske zbirke; 9. Tradicijski obrti, kreativne radionice i izvorni suveniri i 10. Tematske ceste i putovi, staze i itinereri na ruralnom prostoru.

Razvoj ruralnoga turizma u Hrvatskoj operativno provode i potporama pomažu Ministarstvo turizma RH i Ministarstvo poljoprivrede RH. Također, razvoj turizma potporama pomažu i županije, jedinice lokalne samouprave, sporadično i međunarodne institucije, te Hrvatska banka za obnovu i razvoj (HBOR) kreditnim linijama za turizam.

Gotovo sve hrvatske županije donijele su svoje Regionalne operativne programe, odnosno Županijske razvojne strategije. Pojedine hrvatske županije, kao na primjer Međimurska županija, prepoznale su vrijednost svoga ruralnoga prostora i usvojile Strategije ruralnoga razvoja, a tri županije - Zagrebačka, Sisačko-moslavačka i Splitsko-dalmatinska donijele su strateške dokumente razvoja turizma na svom prostoru, s posebnim naglaskom na ruralni turizam. Neke županije, kao što su Istarska, Karlovačka, Ličko-senjska, Bjelovarsko-bilogorska, i druge, posjeduju i master-planove razvoja turizma na svom području. Također, pojedine jedinice lokalne samouprave, primjerice u Osječko-baranjskoj županiji, donijele su vlastite strategije razvoja ili projekte ukupnoga razvoja, koji su temelj njihovoga uspješnog razvoja, među ostalim i ruralnoga turizma.

Od 2005. godine Ministarstvo turizma Republike Hrvatske za razvoj destinacija ruralnoga turizma uz očuvanje identiteta seoskoga prostora u Hrvatskoj dodjeljuje potpore i poticaje kroz dva programa: Programi nepovratnih potpora male vrijednosti i Kreditni programi sa subvencioniranom kamatom. Programi nepovratnih potpora male vrijednosti su: 1. Program poticanja zaštite, obnove i uključivanja u turizam kulturne i prirodne baštine u turistički nerazvijenim područjima - "Baština u turizmu"; 2. Program poticanja razvoja tematskih turističkih putova - "Tematski putovi" i 3. Program poticanja unaprjeđenja izrade i plasmana suvenira - "Izvorni suvenir". Kreditni programi sa subvencioniranom kamatom su: 1. Programi "Poticaj za uspjeh" i "Pod stoljetnim krovovima", i 2. Program kreditiranja ruralnoga turizma "Razvoj turizma na selu".

Programi nepovratnih potpora male vrijednosti dodjeljuju se od 2005., odnosno 2007. godine. Od 2005. godine kontinuirano se dodjeljuju potpore za program "Baština u turizmu", dok se od 2007. godine dodjeljuju potpore i za druga dva programa "Tematski putovi" i "Izvorni suvenir". Prema posljednjim službenim podacima Ministarstva turizma RH o financiranju Programa nepovratnih potpora male vrijednosti, iz 2009. godine, ukupno je financirano 1055 programa u vrijednosti od 42861593 HRK (tablica 7.). 
Tablica 7.

Financiranje programa "Baština u turizmu", "Tematski putovi" i "Izvorni suvenir" od Ministarstva turizma Republike Hrvatske prema ukupnom broju/iznosima po programu od 2005. do 2009. godine

\begin{tabular}{|c|c|c|c|}
\hline Godina & Naziv programa & $\begin{array}{c}\text { Ukupni broj } \\
\text { programa }\end{array}$ & Ukupni iznos u HRK \\
\hline $2005 .-2009$. & Baština u turizmu & 595 & 27061593 \\
\hline $2007 .-2009$. & Tematski putovi & 182 & 10435000 \\
\hline $2007 .-2009$. & Izvorni suvenir & 278 & 5365000 \\
\hline Ukupno & & $\mathbf{1 0 5 5}$ & $\mathbf{4 2 8 6 1 5 9 3}$ \\
\hline
\end{tabular}

Izvor: Ministarstvo turizma Republike Hrvatske, siječanj 2012.

"Baština u turizmu" je program koji je dao izvrsne rezultate, posebno u razvoju kontinentalnoga turizma. U razdoblju od 2005. do 2009. godine dofinancirano je 595 projekata u iznosu od 27061593 HRK. Implementacijom tih projekata oživljena je gospodarska aktivnost, povećan je broj pružatelja turističkih usluga u nerazvijenim turističkim područjima, a obnova tradicionalnih objekata omogućila je obnavljanje starih vještina i zanata i otvorila nove kanale prodaje domaćih proizvoda i usluga. Zaštita baštine potakla je održivi razvoj jer su mnogi objekti arhitektonske baštine (pučka arhitektura, mlinice, kovačnice, i drugi) spašeni od daljnjega propadanja upravo novim turističkim namjenama.

Program "Tematski putovi" započeo je 2007. godine s ciljem da se postigne bolja prepoznatljivost Hrvatske kao cjelovite i raznolike turističke zemlje. Cilj "Tematskih putova" je i da se potakne zanimanje i odluka turista/putnika za kraću stanku, kružno putovanje, kraći odmor ili kombinirani odmor/ljetovanje posjetom kontinentalnih s jadranskim destinacijama, da se strane turiste/putnike, koji već borave u poznatim turističkim destinacijama ili na kružnim putovanjima, pridobije za tematske putove i za manje poznate turističke destinacije, s ciljem povećanja potrošnje i da se stvore tematski integrirane i organizirane turističke atrakcije kroz cijelu godinu povezivanjem prirodnih, kulturnih i povijesnih znamenitosti naše zemlje. Od 2007. do 2009. godine, u sklopu ovoga Programa realizirana su 182 projekta na koje je utrošeno 10435000 HRK.

Iste godine započelo je i ostvarivanje programa "Izvorni suvenir", kojim se željela oživjeti proizvodnja tradicijskih i umjetničkih obrta, potaknuti dopunske aktivnosti (proizvodnja domaćega proizvoda - suvenira) i potvrditi vrijednosti unikatne ručne proizvodnje, potaknuti stvaralaštvo replika, redizajna i novoga dizajn proizvoda, te zaštititi baština i sačuvati je korištenjem tradicijskih tehnika i materijala. Od 2007. do 2009. godine, u okviru ovoga programa ostvareno je ukupno 278 projekata u vrijednosti od 5365000 HRK.

I premda se svake godine povećava broj predloženih i odobrenih projekata, kao i iznosi novčanih potpora za financiranje svakoga od naprijed navedena tri Programa, još uvijek u javnosti nije dovoljno poznat njihov konačni pozitivni učinak. Odnosno, nedovoljno je poznato o kojim projektima je riječ, kako su se uklopili u postojeću 
turističku ponudu i koje pozitivne pomake u razvoju mjesta, lokalne sredine ili županije su donijeli, koji su njihovi pozitivni učinici na gospodarstvo, i drugo. Stoga bi, nakon više godina sustavnoga financiranja ova tri Programa, bila nužna temeljita analiza njihovih rezultata, odnosno realiziranih primjera, koja bi trebala poslužiti, između ostaloga, za preciziranje i artikuliranje kriterija dodjele budućih potpora, ali i kao korektiv ostvarivanja budućih projekata. Također, slijedom dosadašnjih iskustava potrebno je među resornim ministarstvima bolje uskladiti programe kreditiranja i potpora seoskom, odnosno ruralnom turizmu, napraviti analizu do sada odobrenih potpora i programa, te osmisliti kvalitetnije kriterije za dodjelu budućih potpora.

Ministarstva turizma i poljoprivrede imaju i kreditne linije koje se provode u suradnji s Hrvatskom bankom za obnovu i razvoj (HBOR), Hrvatskom agencijom za malo gospodarstvo (HAMAG) i poslovnim bankama. Dva vrlo uspješna, kontinuirano prisutna programa kreditiranja, su program Ministarstva turizma RH i HBOR-a "Poticaj za uspjeh" i "Pod stoljetnim krovovima".

U programu "Poticaj za uspjeh" Ministarstvo turizma Republike Hrvatske subvencionira kamate od 1\% do 4\%, s dugim rokovima otplate do 20 godina, s počekom do dvije godine, dok maksimalni kapaciteti objekata koji se financiraju moraju biti od 10 do 40 soba, odnosno 7 do 20 apartmana, i svaki objekt mora minimalno zadovoljiti uvjete kategorizacije od tri zvjezdice. Od 2002. godine, početka ovoga programa, do 2009. godine, realizirano je 474 kredita (145 kredita na kontinentu, 245 u priobalju i 84 na otocima) u iznosu od 193072787717 HRK. Najveći broj kredita (207) korišten je za izgradnju i obnavljanje smještajnih kapaciteta, a najčešće su financirani hoteli/pansioni/aparthoteli (357), a najmanje kamp odmorišta (6).

U programu "Pod stoljetnim krovovima", kojemu je glavni cilj očuvanje tradicionalne arhitekture, od 2002. do 2009. godine obnovljeno 107 objekata kulturne baštine, od toga njih 17 u kontinentalnim županijama.

Program kreditiranja "Razvoj turizma na selu" namijenjen je fizičkim i pravnim osobama koje su upisane u Upisnik poljoprivrednih gospodarstava i registrirane za ugostiteljsku i turističku djelatnost. U provedbi ovoga kredita sudjeluju Ministarstvo turizma RH, koje subvencionira kamatnu stopu, te poslovne banke - Hrvatska banka za obnovu i razvoj (HBOR) i Hrvatska agencija za malo gospodarstvo (HAMAG). Namjena kredita je stvaranje smještajnih i ugostiteljskih kapaciteta (obnova tradicijskih stambenih i gospodarskih objekata, izgradnja novih, dogradnja i adaptacija postojećih objekata, kupovina postojećih nekretnina) i stvaranje uvjeta za dodatne sadržaje i atrakcije (izgradnja, obnova i uređenje sportsko-rekreativnih i gospodarskih sadržaja, obnova, izgradnja i opremanje objekata i radionica tradicijskih obrta, uređenje pripadajućega okoliša). Ciljevi ovoga programa su razvoj turističke ponude kao dopunske aktivnosti na poljoprivrednim gospodarstvima, povećanje kvalitete života na selu, očuvanje identiteta seoskoga prostora (arhitekture, tradicije, starih zanata) i stvaranje destinacija seoskoga i eko-turizma. Program "Razvoj turizma na selu" započeo je s realizacijom 2009. godine i zasad nema službenih podataka o rezultatima njegove provedbe/implementacije. 
Premda su oba potonja kreditna programa vrlo jasno usmjerena krajnjem cilju jačega gospodarskog razvoja u ruralnim područjima u Hrvatskoj, oba bi trebala biti transparentnija u javnosti jer će na taj način njihovi konkretni krajnji učinci postati vidljivi.

\section{Zaključak i preporuke}

U ovome radu identificirane su posebnosti razvoja ruralnoga turizma Hrvatske koje se prepoznaju u raznim oblicima. Te posebnosti vidljive su u atrakcijsko-motivacijskom temelju ruralnoga turističkog proizvoda Hrvatske.

Istraživanje je ukazalo na posebnosti lokaliteta prirodne i kulturne baštine koji daju kvalitetnu atrakcijsku osnovu ruralnoga turizma Hrvatske, što je, u primjeru hrvatskoga turističkog područja, primijećeno i u određenoj mjeri iskorišteno u oblikovanju ruralnoga turističkog proizvoda.

U Hrvatskoj je oblikovan ruralni turistički proizvod temeljen na uključivanju činitelja ruralnoga tradicijskog identiteta. Jednako tako, u ruralni turistički proizvod Hrvatske je uključena ponuda smještaja turista u tipičnim kamenim i drvenim kućama opremljenim s tradicijskim namještajem. Potom, turistima se nudi hrana pripremljena po receptima i s namirnicama proizvedenima prema tradicijskoj praksi. Nadalje, može se nuditi zabava, sport, rekreacija u prirodnim ambijentima i izgrađenim objektima, te suveniri iz palete proizvoda tradicijskih zanata.

Posebnosti razvoja ruralnoga turizma Hrvatske su i u tome što su za njegov razvoj zainteresirani pojedinci i lokalna zajednica iz čega nastaju brojni posebni oblici ponude i vrste turizma, a lokalna zajednica razvoj turizma prati razvojnom dokumentacijom i putem poticajnih mjera.

Uz navedeno, posebnosti razvoja ruralnoga turizma Hrvatske su i u njegovom ciljanom razvoju u okviru mjera njegove održivosti. U svezi toga sudionici razvoja prepoznaju i shvaćaju vrijednosti prirodne i kulturne baštine, uključujući ih u ruralni turizam.

Na kraju, preporuka je da se identificirane posebnosti razvoja ruralnoga turizma Hrvatske trebaju što bolje istaknuti kako bi ih turisti prepoznali i kako bi se uspostavilo zajedničko razumijevanje svega što destinaciju ili turistički proizvod čini posebnim. Osim toga, posebnosti ruralnoga turizma Hrvatske preporučljivo je uočavati i u postojećim planovima, strategijama, politikama, promidžbenim materijalima i drugim dostupnim dokumentima. 


\section{Literatura}

1. Butler, R. W.; Hall, C. M.; Jenkins, J. M. (1998). Comunity and Change in Rural Tourism - Introduction, u: Butler, R. W.; Hall, C. M.; Jenkins, J. (Ur.). Tourism and recreation in Rural Areas. Chicester: John Wiley and Sons, 3-16.

2. Cetinski, V. i Katica, D. (1998). Turizam i održivi razvitak hrvatskog ruralnog područja, u: Katica Dijana (Ur.). Turizam i održivi razvitak hrvatskog ruralnog prostora. Varaždin: Turistička zajednica grada Varaždina.

3. Cha, S.; MaCleary, M. and Uysual, M. (1995). Travel motivations of Japanese overseas travelers: a factor-cluster segmentation approach. Journal of Travel Research, 33 (2): 33-39.

4. Demonja, D. i Ružić, P. (2010). Ruralni turizam u Hrvatskoj s hrvatskim primjerima dobre prakse i europskim iskustvima. Samobor: Meridijani.

5. Duk-Byeong, P. and Yoo-Shik Y. (2008). Segmentation by Motivation in Rural Tourism: A Korean case study. Tourism Management, 30 (1): 99-108.

6. Frochot, I. (2005). A benefit segmentation of tourists in rural areas: a Scottish perspective. Tourism Management, 26 (3): 335-346.

7. Goeldner, C. R. and Ritchie, J. R. (2003). Tourism: principles, practices, philosophies. Hoboken, NJ: John Wiley \& Sons.

8. Hajek, T. (2002). The Development Potential of Czech Rural Areas and Roral Tourism. Zemedelska Ekonomika (Agricultural Economics), 48 (12): 559-562.

9. Jang, S. and Cai, L. (2002). Travel motivations and destination choice: a study of British outbound market. Journal of Travel and Tourism Marketing, 13 (3): 111-133.

10. Jang, S. and Wu C.-M. E. (2006). Seniors travel motivation and the influential factors: an examination of Taiwanese seniors. Tourism Management, 27 (1): 306-316.

11. Jurcan, V. (1989). Mogućnost razvoja agroturizma - seoskog turizma. Pula: Studij ekonomije turizma „Dr. Mijo Mirković“.

12. Kamping udruženje Hrvatske. Kulturna baština Hrvatske. Pregledano 25. ožujka 2012. (http://www.camping.hr/hr/hrvatska/kulturno-nasljedstvo).

13. Kastenholz, E. and Lima, J. (2011). The Integral Rural Tourism Experience from the Tourist's Point of view - A Qualitative Analysis of its Nature and Meaning. Tourism \& Management Studies, 7: 62-74.

14. Kušen, E. (2007). Kako ugostiti turiste na vlastitom imanju?. Zagreb: Institut za turizam i Austrian Development Cooperation.

15. Kušen. E. (2002). Turistička atrakcijska osnova. Zagreb: Institut za turizam.

16. Kušen, E. (1997). Strateški okvir razvitka ruralnog turizma kao dio koncepta cjekokupnog razvitka ruralnog prostora i obnove sela, u: Katica D. (Ur.). $R u$ ralni turizam - jedan od čimbenika obnove sela $i$ cjelovitog razvitka ruralnog prostora. Zagreb: Hrvatski farmer d.d.

17. Kušen, E. (1995). Turizam na seljačkim gospodarstvima. Turizam, 43 (7/8): 127-133.

18. Lane, B. (2009). Rural Tourism: An Overview, in: Jamal, T., and Robinson, M., (Ur.). The SAGE Handbook of Tourism Studies. London: Sage Publications.

19. Lee, C.; Lee, Y. and Wicks, B. E. (2004). Segmentation of festival motivation by nationality and satisfaction. Tourism Management, 25 (1): 61-70. 
20. Meler, M. (2010). Strateško marketinško planiranje kao pretpostavka razvitka ruralnog turizma Republike Hrvatske, u: Katica Dijana (Ur). Zbornik radova Drugog hrvatskog kongresa o ruralnom turizmu s međunarodnim sudjelovanjem „Koncepcija dugoročnog razvoja ruralnog turizma“, 21.-25. travnja 2010., Mali Lošinj. Zagreb: Hrvatski farmer d.d.

21. Ministarstvo poljoprivrede, ribarstva i ruralnog razvoja Republike Hrvatske (2008). Strategija ruralnog razvoja Republike Hrvatske za razdoblje 2008. 2013. godine. Zagreb: Ministarstvo poljoprivrede, ribarstva i ruralnog razvoja Republike Hrvatske. Pregledano 29. ožujka 2012. (http://www.mps.hr/UserDocsImages/strategije/STRATEGIJA_RR_19-05-081.doc).

22. Ministarstvo turizma Republike Hrvatske (2003). Strategija razvoja hrvatskog turizma do 2010. godine. Zagreb: Ministarstvo turizma Republike Hrvatske. Pregledano 25. veljače 2012. (http://www.mint.hr/UserDocsImages/Strategija\%20hrvatskog\%20turizma\%20-\%20finalna\%20verzija.pdf).

23. Mišćin, L. i Mađer, B. (2008). Aktualno stanje turizma na ruralnom prostoru Hrvatske 2008. Zagreb: Hrvatska gospodarska komora, Sektor za turizam. Pregledano 28. ožujka 2012. (http://hgk.biznet.hr/hgk/fileovi/13081.ppt).

24. Mowl, G. (2001). Leisure and identity of place, in: Pain, R.; Barke, M.; Fuller, D.; Gough, J.; Macfarlane, R.; Mowl, G. (Eds.). Introducing Social Geographies. London: Arnold.

25. Pena, A. I. P.; Jamilena, D. M. F. and Molina, M. A. R. (2012). Validation of Cognitive Image Dimensions for Rural Tourist Destinations, a Contribution to the Management of Rural Tourist Destinations. Journal of Vacation Marketing, 18 (4): 261-273.

26. Ružić, P. (2009). Ruralni turizam. Drugo prošireno izdanje. Pula: Institut za poljoprivredu i turizam Poreč.

27. Strategic Marketing Plan of Croatian Tourism 2010-2014 (2008). THR \& Horwath: Barcelona.

28. UNESCO. Culture. World Heritage Centre. About World Heritage. Croatia. Pregledano 17. studenog 2012. (http://whc.unesco.org/en/statesparties/hr).

29. Weber, S. i Mikačić, V. (1995). Osnove turizma. Zagreb: Školska knjiga.

30. Yoon, Y. and Uysal, M. (2005). An examination of the effects of motivation and satisfaction on destination loyalty: a structural model. Tourism Management, 26 (1): $45-56$. 
Pavlo Ružić

Institute of Agriculture and Tourism Poreč, Croatia

e-mail:pavlo@iptpo.hr

Damir Demonja

Institute for Development and International Relations, Zagreb, Croatia

e-mail:ddemonja@irmo.hr

\title{
Natural and Anthropogenic Basis of Croatian Tourism
}

\begin{abstract}
This paper examines Croatian rural tourism in terms of its natural and social developmental characteristics. The main objective of this research is to recognize Croatian rural tourism development specifics. In relation with this objective the hypothesis is set which states that Croatia has the natural and social attractiveness which enables it to develop a special, interesting, acceptable, competitive and sustainable rural tourism product. Research in this paper is based on secondary sources and the analysis of various approaches to rural tourism and views on it by domestic and foreign authors. The paper has examined and explained the assumption that it is possible to develop rural tourism in Croatia as well as the intensity of this development.
\end{abstract}

Key words: Croatia, rural tourism, rural area, rural tourism product. 